PALAIOS

Emphasizing the impact of life on Earth's history
PALAIOS, 2021, v. 36, 173-181

Research Article

DOI: http://dx.doi.org/10.21 10/palo.2020.073

\title{
MUDDYING THE WATERS: MODELING THE EFFECTS OF EARLY LAND PLANTS IN PALEOZOIC ESTUARIES
}

\author{
MURIEL Z.M. BRÜCKNER, ${ }^{1}$ WILLIAM J. MCMAHON,,${ }^{1,2}$ AND MAARTEN G. KLEINHANS ${ }^{1}$ \\ ${ }^{1}$ Utrecht University, Faculty of Geosciences, Department of Physical Geography, PO box 80115, 3508 TC Utrecht, The Netherlands \\ ${ }^{2}$ Energy and Environment Institute, University of Hull, Cottingham Road, Hull HU6 7RX, UK
}

\begin{abstract}
Aвstract: The Paleozoic evolution of vegetation transformed terrestrial landscapes, facilitating novel sedimentary processes and creating new habitats. This transformation left a permanent mark on the sedimentary record, perhaps most strikingly via an upsurge in preserved terrestrial mudrock. Whereas feedbacks between evolving vegetation and river structure have been widely studied, Paleozoic estuaries have so far received scant attention. Located at the interface between the land and sea, the co-adjustment of estuarine morphology and plant traits are fundamentally tied to a varied range of geochemical cycles, and determine how global silicate weathering patterns may have varied over time. Here we employ an eco-morphodynamic model with an in-built vegetation code to simulate estuarine morphology through five key stages in plant evolution. An abiotic model (early Precambrian?) saw mud deposition restricted to fortuitous instances of limited erosion along bar-flanks. Estuaries colonized by microbial mats (Precambrian onwards) facilitated mud accretion that sufficiently stabilized bar surfaces to promote extensive mudflat development. Small-stature, rootless vegetation (Silurian-Early Devonian) introduced novel above-ground baffling effects which led to notable mud accumulation in lower-energy environments. The incorporation of roots (Early Devonian) strengthened these trends, with root structures decreasing the mortality of the occupying plants. Once the full complement of modern vascular plant architectures had evolved (Middle Devonian), dense colonization promoted the formation of in-channel islands accompanied with system-wide mud accumulation. These simulations suggest estuaries underwent profound change during the Paleozoic, with the greening of the continents triggering processes and feedbacks which render all previous source-to-sink sediment pathways non-uniformitarian.
\end{abstract}

\section{PALEOZOIC FACIES SHIFTS}

The mudstone content of Precambrian terrestrial strata is limited (Long 2011, 2019; McMahon and Davies 2020), with markedly heterolithic deposits only becoming abundant in the Paleozoic (Davies and Gibling 2010; McMahon and Davies 2018) (Fig. 1). This muddying of the continents occurs in stratigraphic alliance with the paleobotanical record, with the shift attributed to the ways in which vegetation enhanced mud production and sediment flux from continental interiors (McMahon and Davies 2018; Zeichner et al. 2021). Plants serve to increase the production of mud directly through enhanced chemical weathering (e.g., Hazen et al. 2013). They also facilitate mud retention on the continents at waterterrestrial interfaces through ecosystem engineering (Jones et al. 1994) which induces: (1) sediment-baffling, the trapping by above-ground plant parts and deposition of suspended sediment through flow deceleration within vegetation structures (Moor et al. 2017; Kleinhans et al. 2018); and (2) sediment-binding, the stabilization of grains by roots and rhizomes (Xue et al. 2016). The bulk of studies that have considered the ties between evolving land plants and the muddying of the continents have focused on the impact of riparian vegetation on riverine processes. Estuaries, conversely, have scarcely been considered; a glaring omission considering these environments were likely gateways for the terrestrialization process (e.g., Strother 2000; Rubinstein et al. 2010). The purpose of this paper is to test if Paleozoic land plants had the capacity to biophysically alter the morphological development of tidal environments, presently inferred only from partial modern analogues (e.g., van de Vijsel et al. 2020) and studies of ancient outcrop belts detached from their formative processes by hundreds of millions of years (e.g., Bradley et al. 2018; Muhlbauer and Fedo 2020; Went 2020). Understanding the precise timing and magnitudes of accelerated terrestrial mud deposition coeval with expanding vegetation cover is fundamental for a range of studies including: (1) controls on deposition in the absence of vegetation (e.g., during the Precambrian Earth or on Mars); (2) mechanisms which enabled continental terrestrialization; (3) the capacity of early land plants to engineer their habitats; (4) functional changes to geochemical cycles which are dependent on sediment-flux; and (5) the potential for evolving functional traits along evolutionary time-scales to alter the physical habitat (Corenblit et al. 2015).

\section{MODELING THE SEDIMENTOLOGICAL IMPACT OF PALEOZOIC LAND PLANTS}

A numerical model that couples a vegetation code to a hydromorphodynamic estuary model (Delft3D) was developed to address the sedimentological impact of evolving Paleozoic land plants (Fig. 2). The model captures feedbacks between ecological and morphological processes by predicting dynamically changing vegetation cover based on the changing environmental parameters (submersion time, flow velocity, and bed level changes) in the hydro-morphodynamic model. Moreover, the presence of biota affects the hydro-morphodynamic processes in the model through eco-engineering effects. Eco-engineering is captured by different parameters, depending on whether microbial mats or vegetation are present: the presence of microbial mats reduces the erodibility of the mud, whereas vegetation structures alter the flow through hydraulic roughness and drag, indirectly protecting the bed through flow baffling (see Online Supplementary File for detailed equations). Any direct impact on the 


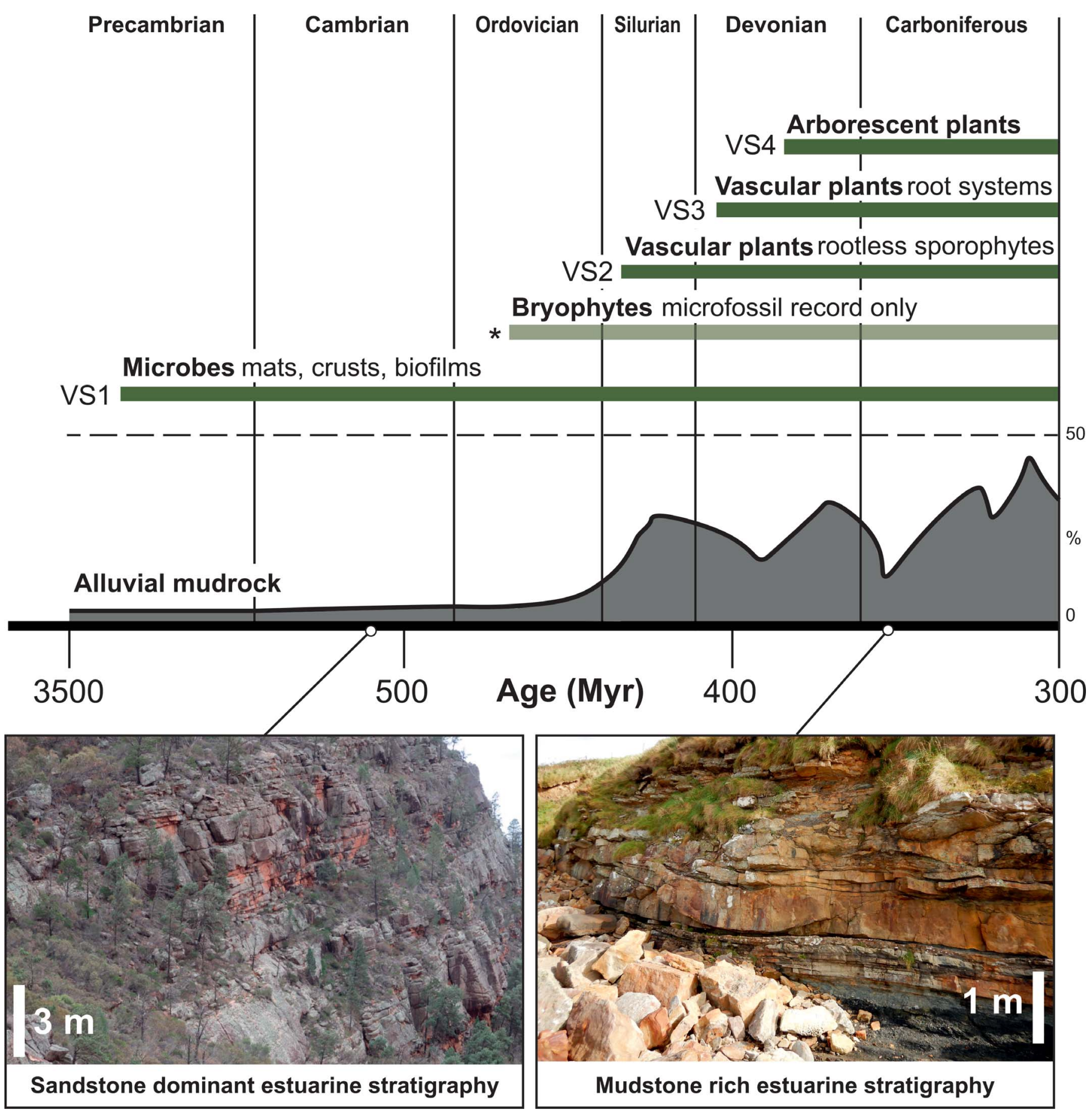

FIG. 1.-Key evolutionary advances of land plants in vegetation stages (VS) (Boyce and Lee 2017; Fischer 2018). Even though bryophytes colonized landscapes as early as the Middle Ordovician (Rubinstein et al. 2010), see asterisk, we neglect this stage as effects of microscopic plant remains (predominantly cryptospores) cannot be parameterized by the model. The mudrock curve is redrawn from McMahon and Davies (2018). Photographs of estuarine successions show sandstone prevalence before vegetation (Rawnsley Quartzite, Australia) (McMahon et al. 2020) and widespread mudstone following the greening of the continents (Shawly Formation, Ireland) (Graham et al. 2014).

mechanical stability of sedimentary substrates caused by root structures was not incorporated as flow baffling was shown to be the main mechanism determining soil stabilization (Kleinhans et al. 2018). The vegetation code and the hydro-morphodynamic model are coupled every sixth month of morphological computations to update the biota distribution based on the environmental parameters, and to feed the resulting change in erodibility or hydraulic roughness and drag back into the Delft3D model. By parameterizing increased environmental resilience through each sequential vegetation stage, the model approximated the estimated increase in plant biomass throughout the Paleozoic (otherwise estimated from the prevalence of spores (Kenrick et al. 2012), isotopic data (Godderis and Joachimski 2004; Malkowski and Racki 2009), or the abundance of plant- 


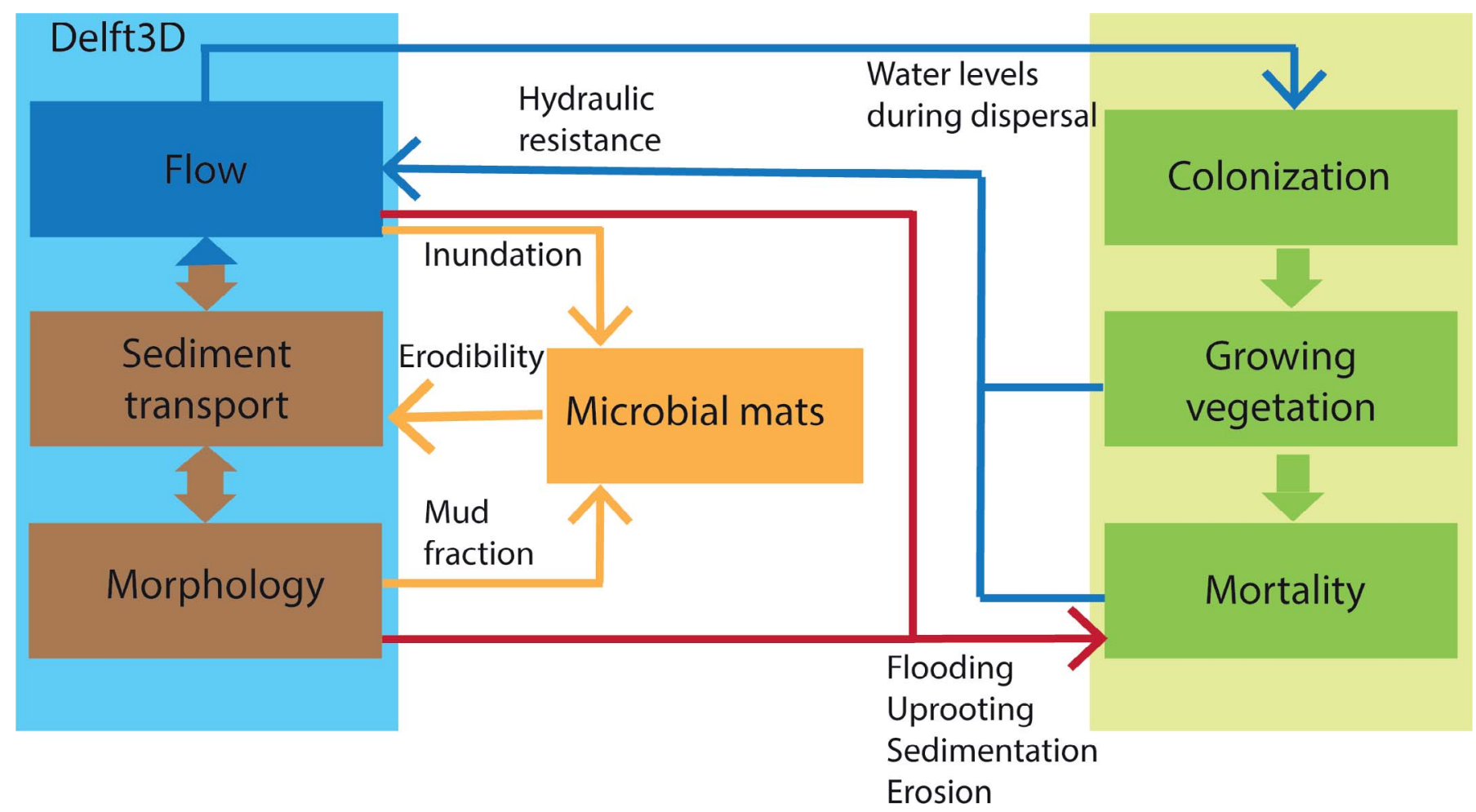

FIG. 2.-Conceptual model of the interactions between the hydro-morphodynamic model (Delft3D) and the vegetation code (from Brückner et al. 2020). The hydromorphodynamic computations are used in the vegetation code to determine (1) occurrence of the microbial mats based on inundation time and mud fraction and (2) colonization and mortality of the vegetation depending on the water levels, flooding time, uprooting and bed level changes. Eco-engineering effects are included in the hydromorphodynamic computations through reduced erodibility of the mud by presence of microbial mats and increasing hydraulic resistance with vegetation growth.

dependent biomaterials (e.g., coal, peat) (Davies et al. 2020). Derived plant characteristics (Figs. 2, 3) enabled computation of feedbacks between vegetation establishment, growth and mortality, and hydromorphology, concurrently enabling analysis of vegetation's impact on sedimentation.

\section{The Idealized Estuary Model}

The model domain consists of an idealized estuary based on the Dyfi Estuary (Wales, UK) that includes a tidal embayment close to the mouth of the estuary. The Dyfi is a well-studied estuary with limited human interference, which allows elucidation of how vegetation encroachment may have affected mud accretion in mainly sandy estuaries (further described in Braat et al. 2017). We assume an alluvial system as there are no constraints to the development of the estuary by bedrock. The length of the entire domain was approximately $42 \mathrm{~km}$ with a slope in the estuarineriver part of $0.155 \%$, a channel width of around $100 \mathrm{~m}$ upstream and $4 \mathrm{~km}$ at the mouth. The model contains both sand and mud, with the former being computed through equilibrium transport at the boundaries and the latter through a constant river supply. The initial bathymetry was chosen after the formation of tidal bars and a natural build-up of a mud cover in sheltered areas and on the floodplains. The modeled estuary shows a gradual fluvial-tidal transition with increasing sand bar dimensions and channel braiding towards the sea. The effect of land plant cover and evolution was captured by an introduction of each vegetation stage to the model separately and comparing the final morphologies with an uncolonized reference run.

The model is forced by an M2-tide of $2 \mathrm{~m}$ amplitude at the seaward model boundary and a constant river discharge of $200 \mathrm{~m}^{3} / \mathrm{s}$ applied from the upstream river boundary. Waves and salinity are neglected as the computation of the former is highly expensive and salinity has only small effects on large-scale sediment transport magnitudes (Braat et al. 2017). Consequently, our focus is on tide-dominated estuaries wherein effects of landward river floods and seaward storms are negligible. To accelerate morphological computations, we applied a morphological acceleration factor of 365 assuming that the bed level changes induced by the flow are constant over longer periods of time (Lesser et al. 2004). This means that erosion and deposition occurring in one tidal cycle are multiplied by 365 , therefore representative of the effect of 365 tidal cycles. The morphological acceleration factor is efficient and widely used to speed up long-term morphodynamic simulations (e.g., Braat et al. 2017).

\section{The Vegetation Model}

We parameterized vegetation growth, sensitivity to environmental pressures through stress tolerance and recovery, and total eco-engineering effects through five distinct Paleozoic 'vegetation stages' (VS) (Fig. 1). The idealization and control enabled exact quantification of species-effects and responses, while excluding the intricacies of real-world systems with complex controls outside the scope of this paper. Our vegetation stages, amended slightly from previous workers for the purpose of appropriate modeling (e.g., Davies and Gibling 2010), mark major advances of vegetation as observed in the paleobotanical record: (1) abiotic (early Precambrian?); (2) biofilms (Precambrian-Cambrian); (3) small-stature, rootless vegetation (Silurian-Early Devonian); (4) rooted tracheophytes (Early Devonian); and (5) arborescent vegetation with deep roots and high resilience to external stresses (Middle Devonian).

The vegetation code is separated into two parts: the first of these defines the establishment of microbial mats (VS1) in areas with inundation periods between $0.3-0.8$ and mud content in the bed above 30\% (Daggers et al. 2018); the second parameterizes vegetation (VS2-VS4) through rules for 


\section{General parameters}

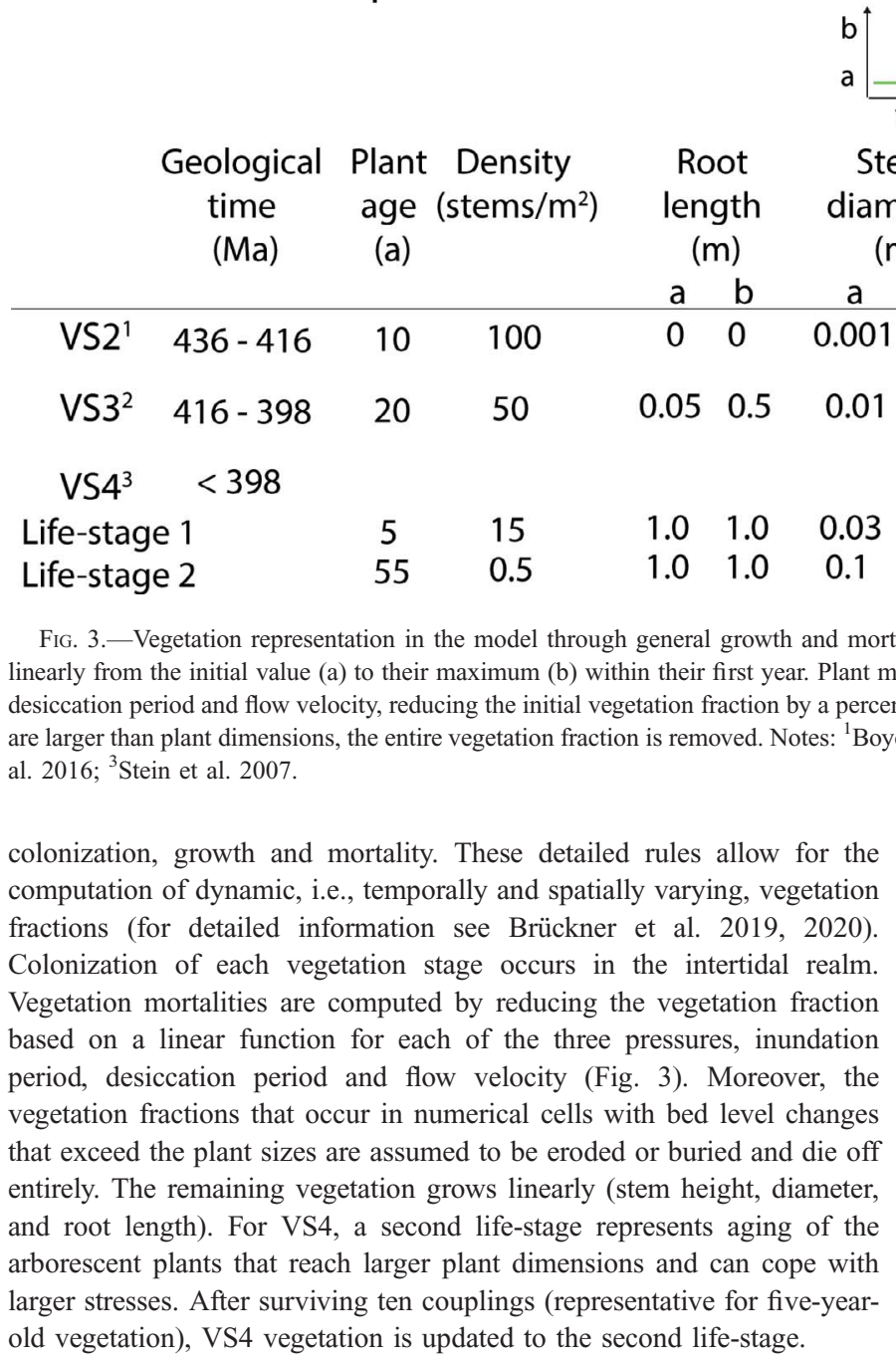

\section{Model Limitations}

We tested a generic species representative for each vegetation stage in isolation in order to generalize the potential impact of evolutionary traits on mud percentages and estuarine morphology. Importantly, this set-up means each sequential vegetation stage is tested independently of the last, meaning that one vegetation stage dominated on the surface, and that any cumulative eco-engineering effects are not captured by the model (i.e., ecoengineering effects felt in VS1 and not captured in the VS2 model run, and so on). Eco-engineering capacities for each vegetation stage should thus be treated as minimums. Besides vegetation type, each model run is carried out under identical settings (boundary and initial conditions, run time, coupling with the vegetation model) in a macrotidal environment with riverine mud supply. The model also neglects any impact on mud production through boosted chemical weathering in the hinterland (e.g., Hazen et al. 2013; Rafiei and Kennedy 2019; Rafiei et al. 2020). This setup enabled direct comparison between the scenario results at the end of a simulated period of 300 years (a sufficient time-period to detect biomorphological change). The modeled estuarine landscape is realistic in morphological and sedimentological properties (Braat et al. 2017; van Lageweg et al. 2018; Brückner et al. 2019) and for the first time allows systematic testing of biogeomorphological processes and their sedimentary products.

\section{The Vegetation Stages}

Vegetation Stage 0.- VS0 includes no biological components, serving as a control run against which the impact of subsequently evolving microbiota and land plants can be measured.

Vegetation Stage 1.-Prior to the advent of land plants, Earth's terrestrial surfaces were not entirely barren, with reports of microbial life in coastal settings extending as far back as the Neoarchean (e.g., Noffke et al. 2006; Wellman and Strother 2015). The mats protect muddy sediments in intertidal areas through the formation of biofilms (e.g., Le Hir et al. 2007), which was accounted for by an increase in the erosion threshold for the mud (see Online Supplemental File).

Vegetation Stage 2.-VS2 begins in the early Silurian and marks the global development of vascular plants (e.g., Gensel et al. 2001; Gensel 2008). Vegetation types were characterized by diverse, centimeter-high sporophytes which lacked rooting structures and only had limited resilience to external stresses. The record of bryophytes actually dates back further to the mid-Ordovician (e.g., Rubinstein et al. 2010; Kenrick et al. 2012; Wellman et al. 2013), but the small dimensions of the plant remains (predominantly cryptospores) could not be parametrized due to limitations in the hydro-morphodynamic model (see Online Supplemental File).

Vegetation Stage 3.-VS3 is marked by the Early Devonian appearance of roots (e.g., Gensel and Berry 2001; Gensel et al. 2001; Hillier et al. 2008; Kenrick et al. 2012; Matsunaga and Tomescu 2016; Hetherington and Dolan 2018). Early rooting structures may not have matched all the characteristics of extant land plants, but likely performed the same functions with regard to soil stabilization and extended down several decimeters into sediment substrates (Xue et al. 2016). Moreover, floras were characterized by increasing plant sizes and frond complexity, with stronger stems and roots making them increasingly resistant to external stresses.

Vegetation Stage 4.- -VS4 marks a number of significant evolutionary advances, including the first evidence of arborescent plant forms (Meyer- 

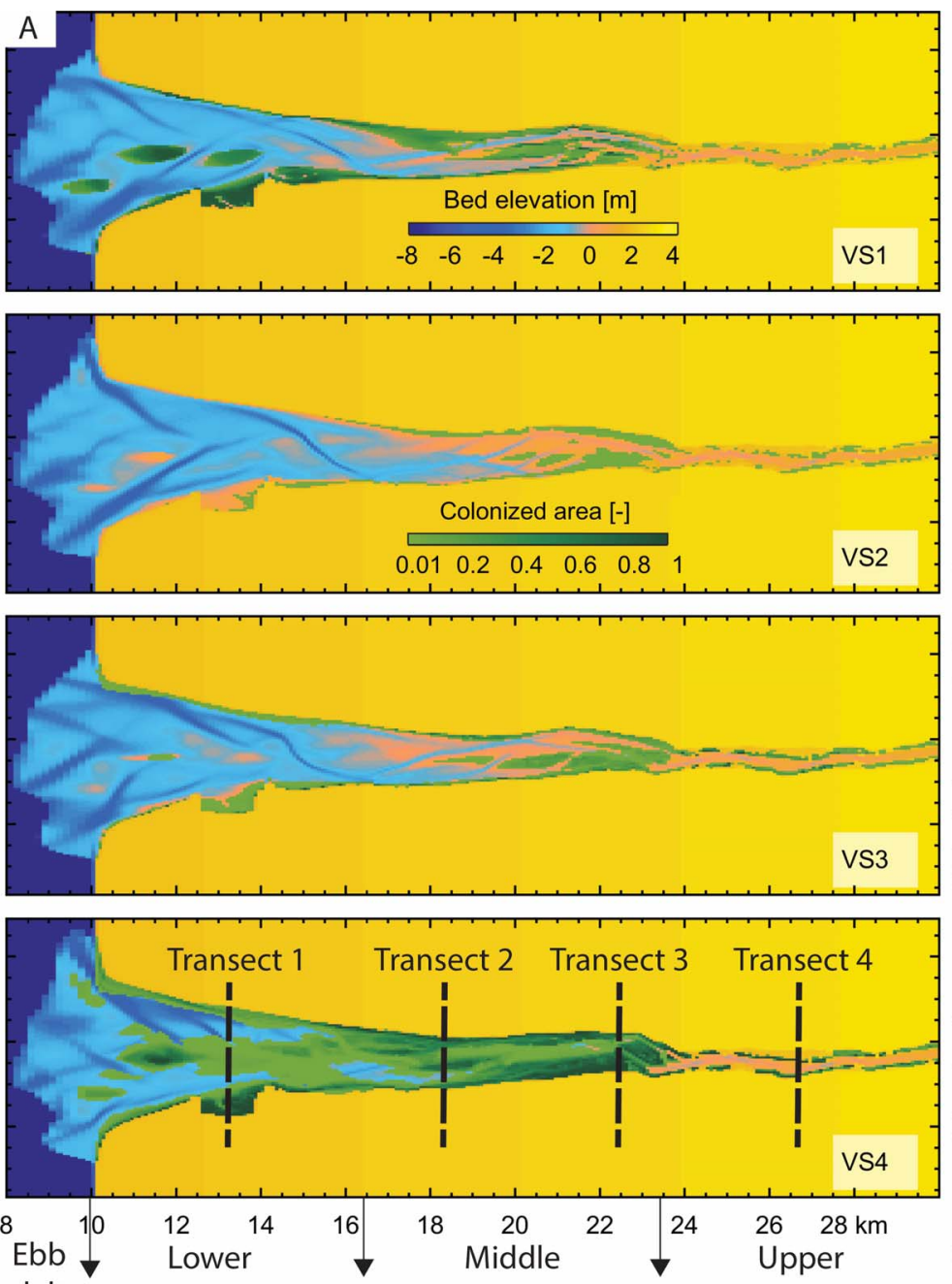

delta

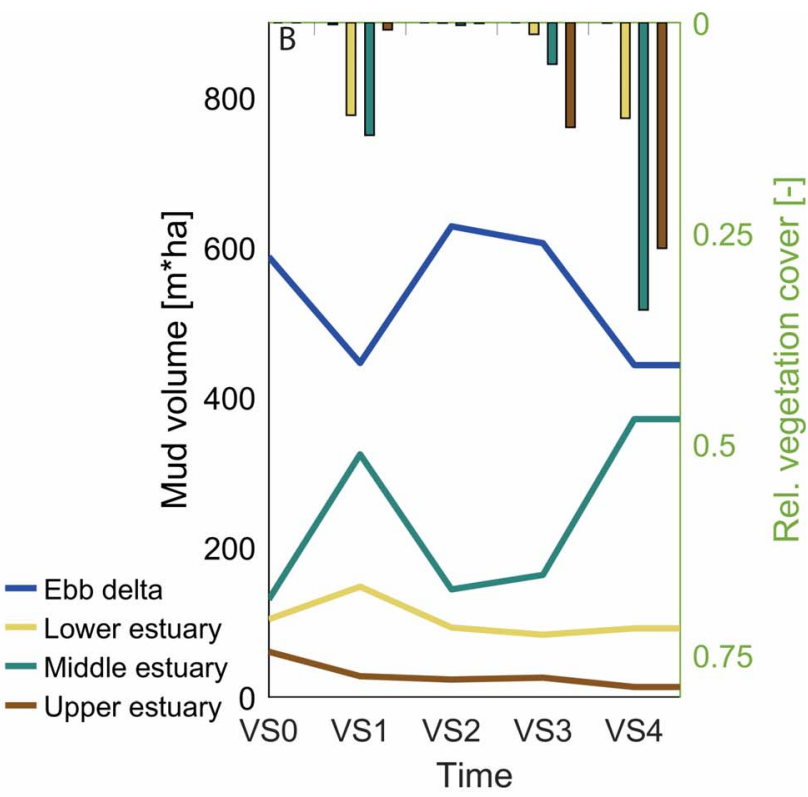

all cells

colonized cells

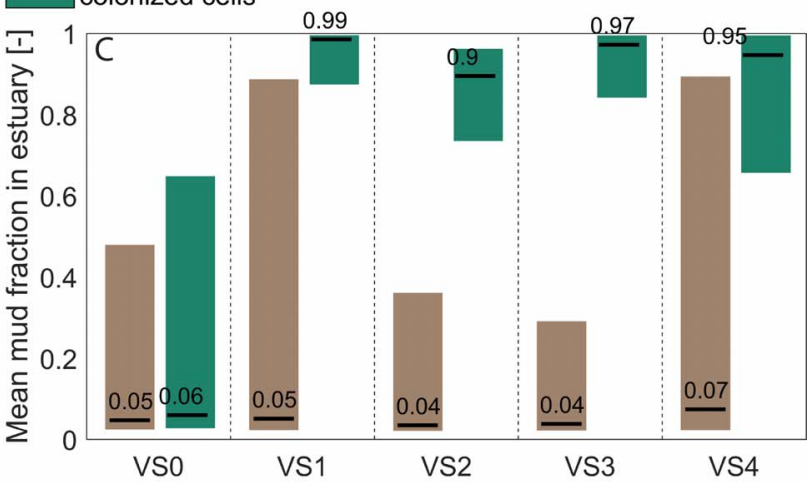

FIg. 4.-Vegetation coverage and related mud volume and fraction in the estuary. A) Bathymetry and mean relative vegetation coverage [1/a] over the simulation period (fraction multiplied with growth period) for all scenarios, showing large coverages for biofilms (VS1) and increasing vegetation abundance through VS2-VS4. B) Relates stored mud volume along estuary (lines for each estuary section) and relative colonized area to entire intertidal domain (bars for each section). Biofilms (VS1) enhance mud retention, particularly in the middle estuary. Whereas increasing vegetation complexity has little effect on the upper estuary, mud is captured in the middle and lower estuary, leading to reduced mud export towards the ebb delta. C) Compares overall mean mud fraction (brown bars) and mean mud fractions in colonized cells (green bars), illustrating that mud is captured within vegetated patches and eroded when vegetation dies-off for VS2-VS3 (in contrast to the system-wide retention of mud in VS1 and VS4). The green bar in VS0 represents the mean mud in the cells colonized in the other scenarios as a control. Bar bottom and top are 25- and 75-percentiles, respectively, black line shows median mud fraction.

Berthaud and Decombeix 2009), the earliest trees (Berry and FaironDemarat 1997), and the first true forests (Stein et al. 2007, 2012, 2020; Berry and Marshall 2015). Whereas VS4 has a Middle Devonian lower limit (Davies and Gibling 2010, their VS6), the upper limit is not defined and extends well into the Carboniferous (Davies and Gibling 2013). The increasingly complex life-cycle of arborescent vegetation leads to the emergence of seedlings and mature life-stages characterized by increasing plant and root sizes (Fig. 3) and even greater life stage-dependent resilience under environmental pressure.

\section{RESULTS}

\section{Vegetation Evolution Affects Mud Accretion in Estuaries}

The abundance of vegetation, and its capacity to retain mud, varied depending on VS and positioning along the decreasing tidal energy gradient from the ebb tidal delta towards the upper estuary (Fig. 4; Online Supplemental File Fig. S1).

Vegetation Stage 0.-Mud was mainly transported towards the ebb delta and offshore (Fig. 4), with fine-sediment retained on the continent largely limited to sheltered areas of the estuary (e.g., channel banks, bartops) (Figs. 4B, 5).

Vegetation Stage 1.-Microbiota colonized extensive floodplain tracts in the middle estuary, as well as on tidal bars within the lower estuary (Fig. 4). In the middle estuary, high rates of mud deposition limited sediment transport towards the ebb delta (Fig. 4B). Overall, biofilm-induced stabilization added sufficient strength to in-channel and bank-attached barforms to facilitate the development of extensive muddy floodplains in conjunction with erosion of the main channel bed (Fig. 5). 

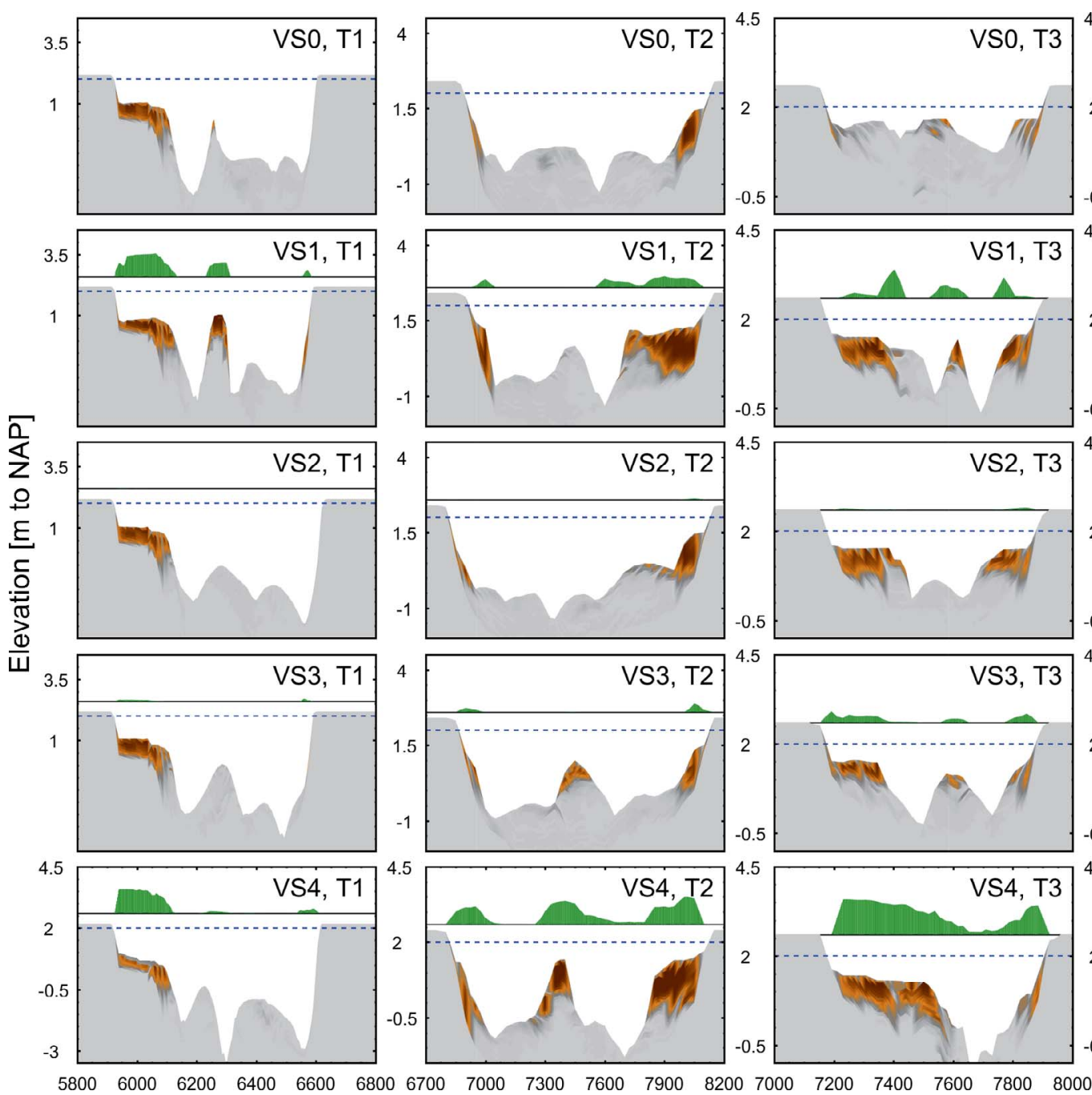

$-0.5$
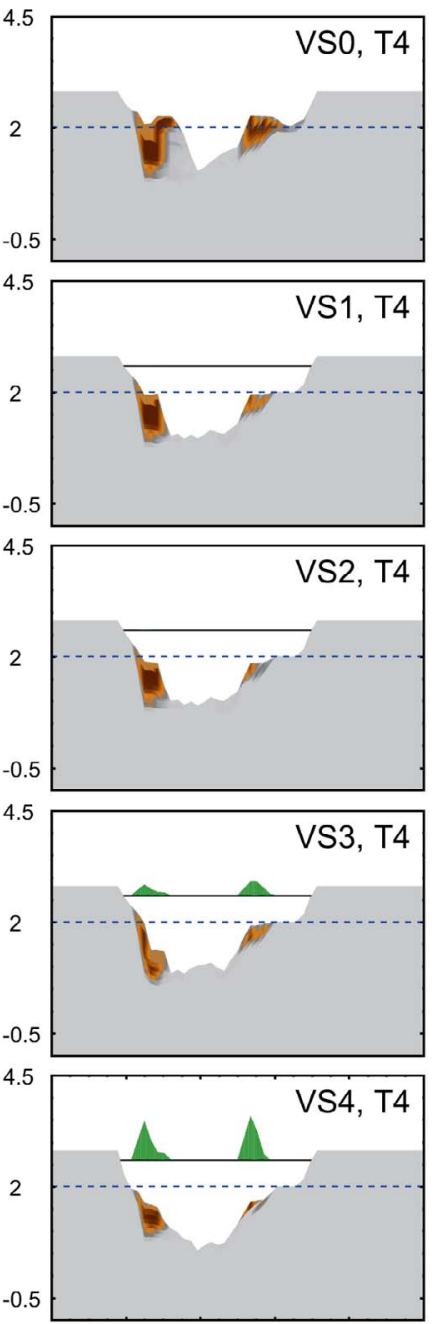

FIG. 5.-Cross-sections (as marked in Fig. 4A) with mud deposits (brown shades represent relative mud content) and qualitative vegetation presence (green bars on black line) for four transects (T1-4). Channel incision and bank slope gradient increases with vegetation complexity while mud and vegetation co-occur along channel banks and on bars from VS3 onwards. Blue dotted line is high water.

Vegetation Stage 2.-The small-stature, rootless vegetation had little effect on upper estuarine processes, with mud being dominantly eroded and transported towards the ebb delta (Fig. 4A, 4B). In the middle estuary, which constitutes calmer conditions overall, flow baffling by above-ground plant parts was far more pronounced, with flow-velocity being sufficiently reduced to promote mud capture and forced deposition. Increased retention of cohesive mud elevated local topography, reducing overland flow strength and further stabilizing the landscape (Fig. 5). The mud fraction was directly correlated to colonized cells, demonstrating that their ecosystem-engineering effects only impacted local bed elevations and stability (Fig. 4C).

Vegetation Stage 3.- Increased resistance against autogenic reworking due to the advent of roots and greater plant sizes led to accelerated colonization and subsequent mud capture within the middle and lower estuary (Fig. 4A). Mud accretion occurred on both in-channel bars and the outer-flanks of the middle-estuary, with sediment-baffling increasingly pronounced due to a more substantial above-ground biomass. Although mean mud concurrent with colonized areas rose, total estuarine mud content was not significantly enhanced (Fig. 4B, 4C). Vegetation largely occupied channel banks, while tidal bars remained dynamic and were only sparsely colonized. Bank stabilization focused flow into the main channels and off floodplains, enhancing the degree of channel incision (Fig. 5). Both channel incision and increasing floodplain elevation through mud deposition gradually reduced mud transport towards the intertidal zone as it partially filled, instead promoting mud export towards the ebb delta.

Vegetation Stage 4.-Complex phenotypes with deep roots facilitated the expansion of vegetation and promoted deposition of muddy sediment on bars and banks. The middle and lower estuary were most substantially affected, with lowered plant mortality promoting the development of dense forests on lower estuary floodplains and tidal bars (Fig. 4A). Such greened areas were capable of withstanding significant hydrodynamic pressure, with enhanced mud stabilization leading to the first true vegetated islands. Mud deposition markedly decreased down-system towards the lower-estuary, with muddy sediments being primarily captured in mud-flats towards estuary flanks (Fig. 4B). Moreover, extensive vegetation cover resulted in system-wide mud preservation, as opposed to the localized effects felt in VS2-3 (Fig. 4C). The extensive stabilization of estuarine banks caused deeper incision and steeper channel margins (Fig. 5). 


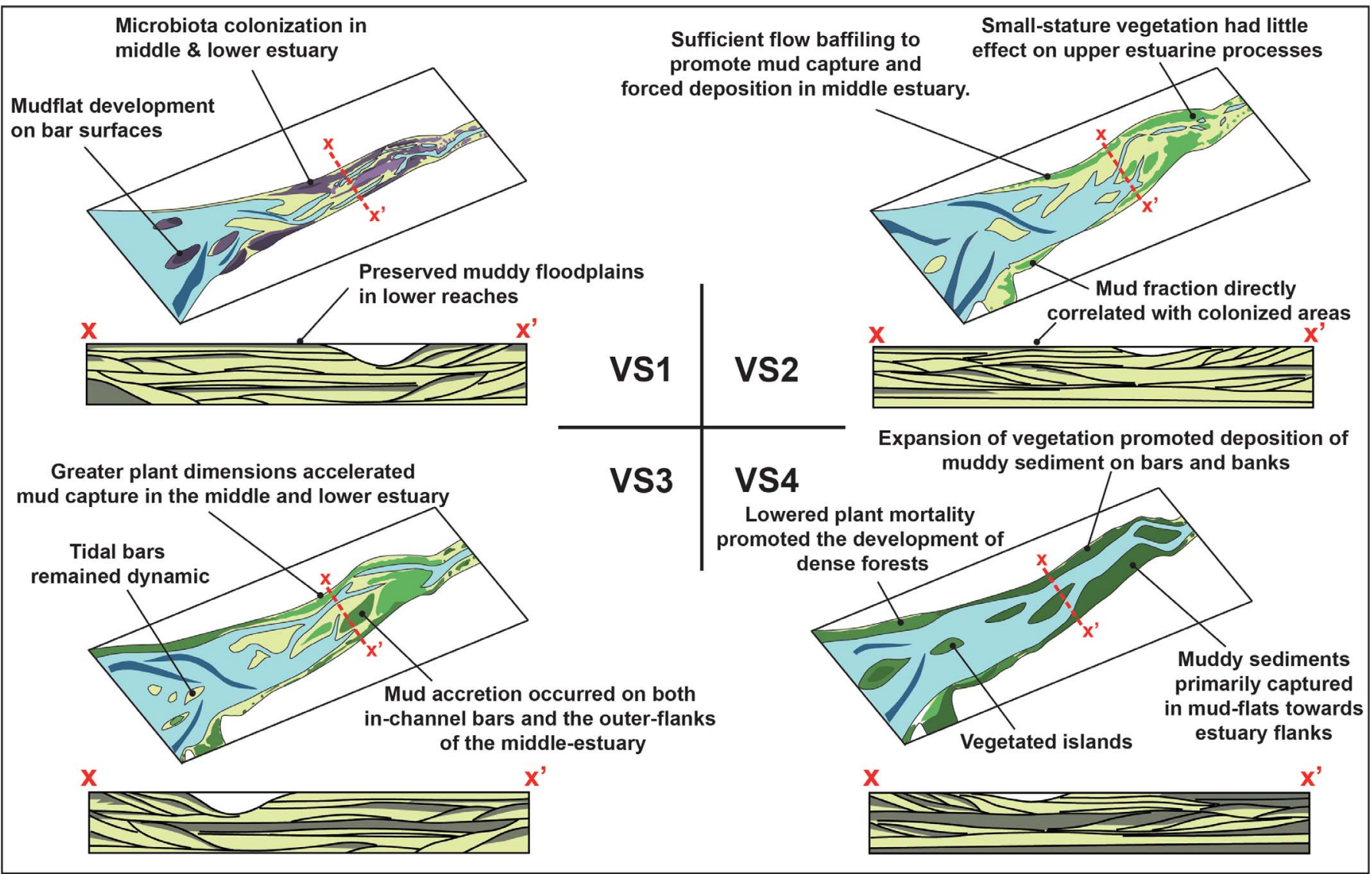

FIG. 6.-Conceptual diagram highlighting key trends in estuarine morphology, stratigraphy, and characteristic vegetation responses and effects throughout vegetation stages 1 to 4 , as indicated by the Delft3D model.

\section{BAFFLING BY VEGETATION INDUCED A RISE IN PALEOZOIC MUDROCK}

\section{Flow-Baffling Depends on Plant Resilience}

Before the Paleozoic expansion of vegetation, biofilms may have had a pronounced impact on estuarine mud accumulation (Fig. 6). Whereas the local sediment stabilizing effect of microbiota in tidal environments has been widely recognized (e.g., Widdows et al. 2004; Le Hir et al. 2007), any system-wide impacts are understudied. However, using the modeled estuary here, we can infer that the encroachment of microbiota on intertidal flats led to localized but significant mud accretion. As in extant estuaries, vegetation size and density control mud accretion (e.g., Leonard and Luther 1995; Brückner et al. 2020) such that increasing vegetation coverage throughout the Paleozoic likely induced further mud preservation. The capacity of plants to expand their habitats from sheltered to dynamic environments is owed to: (1) increased resilience to external stresses (submersion time, drought period, flow velocity, and bed-level changes) via the evolution of roots; and (2) their increased flow-baffling capacity due to enlarged above-ground dimensions. This resulted in new land plant adaptations, which forged new habitat spaces for subsequently evolving fauna and thereby modified estuarine morphology (Fig. 6). It is presumed that the terrestrialization of the continents by land plants began in coastal regions (e.g., Rubinstein et al. 2010) but the salinity tolerances of many early vegetation types remain relative unknown (see discussion in Raymond et al. 2010). Extant salt marsh species are ubiquitously angiosperms (which did not evolve until the Mesozoic; Friis et al. 2006), meaning different flora must have constituted any Paleozoic equivalent. Halophily had certainly evolved by the Early Devonian (VS3), as evidenced by the Rhynie Chert Lagerstätte (Channing and Edwards 2009). By the Carboniferous (VS4) many vegetation types occurred within water-stressed clastic environments (e.g., Gastaldo 1986; Rygel et al. 2006). Whether any identified rooted horizons in Paleozoic marginal marine strata represent definitive salt marsh flora are usually restricted by available sedimentological evidence, with the rooted substrate needing to host clear evidence for inundation on a tidal rhythm by the sea (Davies et al. 2020). As a result of these uncertainties, we make the assumption that the modeled vegetation types could tolerate salinity. The importance of rooting varies with system size and style (e.g., Perona et al. 2012) and whereas the mechanically binding effects of roots play an important part in stabilizing moderate-sized banks, in cases where channel dimensions vastly exceeded root length, systematic undercutting is likely to have been prevalent (Kleinhans et al. 2018). By the Carboniferous, complex root strategies come with resilient, dense plant fractions that promoted sediment stability and aggradation of shores, bars and islands. By reducing plant mortality, the development of significant roots was significant in the encroachment of vegetation towards more dynamic estuarine environments, subsequently resulting in substantial modifications to source-to-sink sediment transport.

\section{Ecosystem Engineering on the Rise}

Our modeling efforts feed into debates concerning the capacity for early vegetation types to ecosystem-engineer their habitats (Davies et al. 2017; Santos et al. 2017). Santos et al. (2017) provided an abiotic account for Earth's tangible rise in Paleozoic mudrock (Fig. 1). In their model, a specific continental configuration was linked to increased tropical 
weathering and thus heightened quantities of mud production. The critical notion underlying their model, namely that primitive rootless land plants were likely ill-equipped to modify sediment flux substantially, constitutes a hypothesis here suggested untrue. Early rootless land plants may have been adequately equipped to engineer their landscapes through flow-baffling (Fig. 5), with the evolution of novel plant-obstacles heightening the deposition of suspended sediment. Any retained cohesive material would lead to increases in the elevation of the local topography, alterations which served to further reduce overland flow velocity and facilitate additional mud deposition.

\section{Vegetation Baffling Reduces Mud Bypassing}

The evolution of large and complex phenotypes, in combination with deep rooting, led to a shift from locally constrained mud preservation in colonized subenvironments towards the system-wide deposition of mud. Extensive retention of mud within estuaries may have compensated for increased export of fine sediments towards the ocean as a result of weathering of the hinterland induced by extensive plant coverages upstream. As we compared each vegetation stage separately, the results reveal a proportional increase in mud deposition related to the evolution of novel plant characteristics. Increasing mud supply induced by chemical weathering of the hinterland and the combined effects of the vegetation stages from the Silurian onwards possibly led to larger net alteration of estuarine landscapes that requires further study. This suggests that from the Paleozoic, estuaries no longer acted as a passive sediment bypass to the oceans, a changing system-behavior which has important implications for how we treat Earth's ancient geochemical cycles. In addition to potentially enhancing the infilling process of estuaries, this mechanism could have similarly mitigated changing climatic impacts, such as increasing rainfall and sea level rise that forced drowning or transgression of non-vegetated landscapes.

\section{CONCLUSIONS}

Numerical models attest that the expansion of terrestrial flora in the Paleozoic induced novel conditions susceptible to extensive mud accumulation in estuarine environments. Permanent changes to estuarine morphology were promoted by the colonization of microbial mats that enhanced mud accretion on sandy bars and shores (early in the Precambrian). The evolution of primitive, rootless vegetation (SilurianEarly Devonian) birthed new flow-baffling processes which further heightened mud deposition in quiescent environments. By reducing local flow velocities, above ground plant parts promoted bed level accretion and flow deviation towards main channels, better protecting previously exposed areas from later erosion. Following the Devonian invention of roots, mud retention substantially increased, as raised plant resilience to external environmental stresses allowed the generation of new habitat. In the modeled estuary, muddy sediment was abundant in all reaches by the late Devonian, facilitating a shift from a locally constrained mud accrual to a system-wide increase in mud deposition. Consequently, proportionally far less mud-grade sediment was bypassed to the marine realm, a transformation in source-to-sink transport that holds significant ramifications for pre-vegetation geochemical cycling.

\section{ACKNOWLEDGMENTS}

This research was funded by the ERC Consolidator project 647570 . We thank Martin Gibling and one anonymous reviewer for their useful comments which greatly helped improve this manuscript. The authors contributed in the following proportions to conception and design, modeling, analysis and conclusions, and manuscript preparation: $\operatorname{MZMB}(50,100,50,40 \%), \operatorname{WJM}(35,0,30,40 \%)$, and $\operatorname{MGK}(15,0,20,20 \%)$

\section{SUPPLEMENTAL MATERIAL}

Data are available from the PALAIOS Data Archive: https://www.sepm.org/supplemental-materials.

\section{REFERENCES}

Algeo, T.J. and ScheCKLER, S.E., 1998, Terrestrial-marine teleconnections in the Devonian: links between the evolution of land plants, weathering processes, and marine anoxic events: Philosophical Transactions of the Royal Society of London Series B: Biological Sciences, v. 353, p. 113-130.

Berry, C.M. and Fairon-Demaret, M., 1997, A reinvestigation of the cladoxylopsid Pseudosporochnus nodosus Leclercq et Banks from the Middle Devonian of Goé, Belgium: International Journal of Plant Sciences, v. 158, p. 350-372.

Berry, C.M. and Marshall, J.E.A., 2015, Lycopsid forests in the early Late Devonian paleoequatorial zone of Svalbard: Geology, v. 43, p. 1043-1046.

Boyce, C.K., 2008, How green was Cooksonia? The importance of size in understanding the early evolution of physiology in the vascular plant lineage: Paleobiology, v. 34, p. 179-194.

Boyce, C.K. And Lee, J.E., 2017, Plant evolution and climate over geological timescales: Annual Review of Earth and Planetary Sciences, v. 45, p. 61-87.

Braat, L., Kessel, T.V., Leuven, J.R., and Kleinhans, M.G., 2017, Effects of mud supply on large-scale estuary morphology and development over centuries to millennia: Earth Surface Dynamics, v. 5, p. 617-652.

Bradley, G.M., Redfern, J., Hodgetts, D., George, A.D., and Wach, G.D., 2018, The applicability of modern tidal analogues to pre-vegetation paralic depositional models: Sedimentology, v. 65, p. 2171-2201.

Brǘckner, M.Z.M., BraAt, L., Schwarz, C., and Kleinhans, M.G., 2020, What came first, mud or biostabilizers? Elucidating interacting effects in a coupled model of mud, saltmarsh, microphytobenthos, and estuarine morphology: Water Resources Research, v. 56, DOI: e2019WR026945.

Brückner, M.Z.M., Schwarz, C., Van DiJK, W.M., Van Oorschot, M., Douma, H., AND Kleinhans, M.G., 2019, Salt marsh establishment and eco-engineering effects in dynamic estuaries determined by species growth and mortality: Journal of Geophysical Research: Earth Surface, v. 124, p. 2962-2986.

Channing, A. AND EDWARds, D., 2009, Silicification of higher plants in geothermally influenced wetlands: Yellowstone as a Lower Devonian Rhynie analog: PALAIOS, v. 24, p. 505-521.

Corenblit, D., Baas, A., Balke, T., Bouma, T., Fromard, F., Garófano-Gómez, V., González, E., Gurnell, A.M., Hortobágyi, B., Julien, F., And Kim, D., 2015, Engineer pioneer plants respond to and affect geomorphic constraints similarly along waterterrestrial interfaces world-wide: Global Ecology and Biogeography, v. 24, p. 13631376.

Daggers, T.D., Kromkamp, J.C., Herman, P.M., and Van Der Wal, D, 2018, A model to assess microphytobenthic primary production in tidal systems using satellite remote sensing: Remote Sensing of Environment, v. 211, p. 129-145.

Davies, N.S. And Gibling, M.R., 2010, Cambrian to Devonian evolution of alluvial systems: the sedimentological impact of the earliest land plants: Earth-Science Reviews, v. 98(3-4), p. 171-200.

Davies, N.S. and Gibling, M.R., 2013, The sedimentary record of Carboniferous rivers: continuing influence of land plant evolution on alluvial processes and Palaeozoic ecosystems: Earth-Science Reviews, v. 120, p. 40-79.

Davies, N.S., Gibling, M.R., McMahon, W.J., Slater, B.J., Long, D.G.F., Bashforth, A.R., Berry, C.M., Falcon-Lang, H.J., Gupta, S., Rygel, M.C., and Wellman, C.H., 2017, Discussion on 'Tectonic and environmental controls on Palaeozoic fluvial environments: reassessing the impacts of early land plants on sedimentation': Journal of the Geological Society, v. 174, p. 947-950, doi: 10.1144/jgs2016-063.

Davies, N.S., Shillito, A.P., Slater, B.J., Liv, A.G., and McMahon, W.J., 2020, Evolutionary synchrony of Earth's biosphere and sedimentary-stratigraphic record: Earth-Science Reviews, v. 201, p. 102979.

Elick, J.M., Driese, S.G., And Mora, C.I., 1998, Very large plant and root traces from the Early to Middle Devonian: implications for early terrestrial ecosystems and atmospheric p (CO2): Geology, v. 26, p. 143-146.

Fischer, W.W., 2018, Early plants and the rise of mud: Science, v. 359, p. 994-995.

Fris, E.M., Pedersen, K.R., and Crane, P.R., 2006, Cretaceous angiosperm flowers: innovation and evolution in plant reproduction: Palaeogeography, Palaeoclimatology, Palaeoecology, v. 232(2-4), p. 251-293.

GASTALDO, R.A., 1986, Implications on the paleoecology of autochthonous lycopods in clastic sedimentary environments of the Early Pennsylvanian of Albama: Palaeogeography, Palaeoclimatology, Palaeoecology, v. 53(2-4), p. 191-212.

Gensel, P.G., 2008, The earliest land plants: Annual Review of Ecology, Evolution, and Systematics, v. 39, p. 459-477.

Gensel, P.G. AND BerRY, C.M., 2001, Early lycophyte evolution: American Fern Journal, v. 91(3), p. 74-98.

Gensel, P.G., Kotyk, M.E., And Basinger, J.F., 2001, Morphology of above-and belowground structures in Early Devonian (Pragian-Emsian) plants, in P.G. Gensel and D. 
Edwards (eds.), Plants Invade the Land: Evolutionary and Environmental Perspectives: Columbia University Press, New York, NY, p. 83.

GodDÉRIS, Y. AND JOACHIMSKI, M.M., 2004, Global change in the Late Devonian: modelling the Frasnian-Famennian short-term carbon isotope excursions: Palaeogeography, Palaeoclimatology, Palaeoecology, v. 202(3-4), p. 309-329.

Graham, J.R., Bhroin, C.N., and Sevastopulo, G.D., 2014, The Carboniferous geology of northern Donegal Bay: Irish Journal of Earth Sciences, v. 32, p. 29-54

Hazen, R.M., Sverjensky, D.A., Azzolini, D., Bish, D.L., Elmore, S.C., Hinnov, L., And MiLliken, R.E., 2013, Clay mineral evolution: American Mineralogist, v. 98, p. 2007 2029

Hetherington, A.J. And Dolan, L., 2018, Stepwise and independent origins of roots among land plants: Nature, v. 561 , p. $235-238$.

Hillier, R.D., Edwards, D., and Morrissey, L.B., 2008, Sedimentological evidence for rooting structures in the Early Devonian Anglo-Welsh Basin (UK), with speculation on their producers: Palaeogeography, Palaeoclimatology, Palaeoecology, v. 270, p. 366-380.

Jones, C. G., Lawton, J. H., AND ShachaK, M., 1994, Organisms as ecosystem engineers, in F.B. Samson and F.L. Knopf (eds.), Ecosystem Management: Springer, New York, NY, p. 130-147, doi: 10.1007/978-1-4612-4018-1_14.

Kenrick, P. and Crane, P.R., 1997, The origin and early evolution of plants on land: Nature, v. 389 , p. 33-39.

Kenrick, P., Wellman, C.H., Schneider, H., and Edgecombe, G.D., 2012, A timeline for terrestrialization: consequences for the carbon cycle in the Palaeozoic: Philosophical Transactions of the Royal Society B: Biological Sciences, v. 367, p. 519-536.

Kleinhans, M.G., De Vries, B., Braat, L., and Van Oorschot, M., 2018, Living landscapes: muddy and vegetated floodplain effects on fluvial pattern in an incised river: Earth Surface Processes and Landforms, v. 43, p. 2948-2963.

Le Hir, P., Monbet, Y., And Orvain, F., 2007, Sediment erodability in sediment transport modelling: can we account for biota effects?: Continental Shelf Research, v. 27, p. 11161142 .

LeONARD, L.A. AND Luther, M.E., 1995, Flow hydrodynamics in tidal marsh canopies: Limnology and Oceanography, v. 40, p. 1474-1484.

Lesser, G.R., Roelvink, J.V., Van Kester, J.A.T.M., and Stelling, G.S., 2004 , Development and validation of a three-dimensional morphological model: Coastal Engineering, v. 51, p. 883-915.

Long, D.G.F., 2011, Architecture and depositional style of fluvial systems before land plants: a comparison of Precambrian, early Paleozoic, and modern river deposits, in S.K. Davidson S. Leleu, and C.P. North (eds.), From River to Rock Record: The Preservation of Fluvial Sediments and their Subsequent Interpretation: Society for Sedimentary Geology (SEPM) Special Publication 97, p. 37-61.

LonG, D.G.F., 2019, Archean fluvial deposits: a review: Earth-Science Reviews, v. 188, p. $148-175$.

MALKOWSKI, K. AND RACKI, 2009, A global biogeochemical perturbation across the Silurian-Devonian boundary: ocean-continent-biosphere feedbacks: Palaeogeography, Palaeoclimatology, Palaeoecology, v. 276, p. 244-254.

Matsunaga, K.K. and Tomescu, A.M., 2016, Root evolution at the base of the lycophyte clade: insights from an Early Devonian lycophyte: Annals of Botany, v. 117, p. 585-598.

McMahon, W.J. AND DaviES, N.S., 2018, Evolution of alluvial mudrock forced by early land plants: Science, v. 359, p. 1022-1024.

McMahon, W.J. And Davies, N.S., 2020, Physical and biological functioning in Proterozoic rivers: evidence from the archetypal pre-vegetation alluvium of the Torridon Group, NW Scotland: Scottish Journal of Geology, v. 56, p. 1-29.

McMahon, W.J., Liu, A.G., Tindal, B., And Kleinhans, M.G., 2020, Ediacaran life close to land: coastal and shoreface habitats of the Ediacaran macrobiota, the central IkaraFlinders Ranges, South Australia: Journal of Sedimentary Research, v. 90, p. 1463-1499, doi: 10.2110 /jsr.2020.029.

Meyer-Berthaud, B. and Decombeix, A.L., 2009, L'évolution des premiers arbres: les stratégies dévoniennes: Comptes Rendus Palevol, v. 8, p. 155-165.

Moor, H., Rydin, H., Hylander, K., Nilsson, M.B., Lindborg, R., and Norberg, J., 2017, Towards a trait-based ecology of wetland vegetation: Journal of Ecology, v. 105, p. $1623-1635$.

Munlbauer, J.G. And Fedo, C.M., 2020, Architecture of a river-dominated, wave-and tideinfluenced, pre-vegetation braid delta: Cambrian middle member of the Wood Canyon Formation, southern Marble Mountains, California, USA: Journal of Sedimentary Research, v. 90, p. 1011-1036.
Noffke, N., Eriksson, K.A., Hazen, R.M., and Simpson, E.L., 2006, A new window into early Archean life: microbial mats in Earth's oldest siliciclastic tidal deposits (3.2 Ga Moodies Group, South Africa): Geology, v. 34, p. 253-256.

Perona, P., Molnar, P., Crouzy, B., Perucca, E., Jiang, Z., Mclelland, S., Wüthrich, D. Edmaier, K., Francis, R., Camporeale, C., and Gurnell, A., 2012, Biomass selection by floods and related timescales: part 1, experimental observations: Advances in Water Resources, v. 39, p. 85-96

RafieI, M. AND KenNEDY, M., 2019, Weathering in a world without terrestrial life recorded in the Mesoproterozoic Velkerri Formation: Nature Communications, v. 10, p. 1-9.

Rafiei, M., Löhr, S., Baldermann, A., Webster, R., And Kong, C., 2020, Quantitative petrographic differentiation of detrital vs diagenetic clay minerals in marine sedimentary sequences: implications for the rise of biotic soils: Precambrian Research, v. 350, p. 105948

Raymond, A., Lambert, L., Constanza, S., Slone, E.J., and Cutlip, P.C., 2010, Cordaiteans in paleotropical wetlands: an ecological re-evaluation: International Journal of Coa Geology, v. 83 , p. $248-265$.

Rubinstein, C.V., Gerrienne, P., De La Puente, G.S., Astini, R.A., and Steemans, P., 2010, Early Middle Ordovician evidence for land plants in Argentina (eastern Gondwana) New Phytologist, v. 188, p. 365-369.

Rygel, M.C., Calder, J.H., Gibling, M.R., Gingras, M.K., Melrose, C.S., Greb, S.F., And Dimichele, W.A., 2006, Tournaisian forested wetlands in the Horton Group of Atlantic Canada: Geological Society of America Special Papers, v. 399, p. 103.

Santos, M.G., Mountney, N.P., Peakall, J., Thomas, R.E., Wignall, P.B., and Hodgson, D.M., 2017, Reply to Discussion on 'Tectonic and environmental controls on Palaeozoic fluvial environments: reassessing the impacts of early land plants on sedimentation': Journal of the Geological Society, v. 174, p. 950-952.

Stein, W.E., Berry, C.M., Hernick, L.V., and Mannolini, F., 2012, Surprisingly complex community discovered in the mid-Devonian fossil forest at Gilboa: Nature, v. 483, p. 78 81 .

Stein, W.E., Berry, C.M., Morris, J.L., Hernick, L.V., Mannolini, F., Ver Straeten, C., Landing, E., Marshall, J.E., Wellman, C.H., Beerling, D.J., and Leake, J.R., 2020 Mid-Devonian Archaeopteris roots signal revolutionary change in earliest fossil forests: Current Biology, v. 30, p. 421-431.

Stein, W.E., Mannolini, F., Hernick, L.V., Landing, E., and Berry, C.M., 2007, Gian cladoxylopsid trees resolve the enigma of the Earth's earliest forest stumps at Gilboa: Nature, v. 446, p. 904-907.

Strother, P.K., 2000, Cryptospores: the origin and early evolution of the terrestrial flora: The Paleontological Society Papers, v. 6, p. 3-20.

Van De Lageweg, W.I., Braat, L., Parsons, D.R., and Kieinhans, M.G., 2018, Controls on mud distribution and architecture along the fluvial-to-marine transition: Geology, v. 46, p. 971-974.

Van De Vijsel, R.C., Van Belzen, J., Bouma, T.J., Van Der Wal, D., Cusseddu, V., Purkis, S.J., RietKerk, M., And VAn De Koppel, J., 2020, Estuarine biofilm patterns: modern analogues for Precambrian self-organization: Earth Surface Processes and Landforms, v. 45 , p. $1141-1154$

Wellman, C.H., Steemans, P., And Vecoli, M., 2013, Chapter 29 Palaeophytogeography of Ordovician-Silurian land plants: Geological Society of London Memoirs, v. 38, p. 461-476.

Wellman, C.H. and Strother, P.K., 2015, The terrestrial biota prior to the origin of land plants (embryophytes): a review of the evidence: Palaeontology, v. 58, p. 601-627.

Widdows, J., Blauw, A., Heir, C.H.R., Herman, P.M.J., Lucas, C.H., Middelburg, J.J., Schmidt, S., Brinsley, M.D., Twisk, F., And Verbeek, H., 2004, Role of physical and biological processes in sediment dynamics of a tidal flat in Westerschelde Estuary, SW Netherlands: Marine Ecology Progress Series, v. 274, p. 41-56.

WENT, D.J., 2020, Fluvial shoal water deltas: pre-vegetation sedimentation through the fluvial-marine transition, lower Cambrian, English Channel region: Sedimentology, v. 67 p. 330-363.

Xue, J., Deng, Z., Huang, P., Huang, K., Benton, M.J., Cui, Y., Wang, D., Liu, J., Shen, B., BASINGER, J.F., AND HAO, S., 2016, Belowground rhizomes in paleosols: the hidden half of an Early Devonian vascular plant: Proceedings of the National Academy of Sciences, v. 113, p. $9451-9456$.

Zeichner, S.S., Nghiem, J., Lamb, M.P., Takashima, N., De Leeuw, J., Ganti, V., and FISCHER, W.W., 2021, Early plant organics increased global terrestrial mud deposition through enhanced flocculation: Science, v. 371, p. 526-529.

Received 3 November 2020; accepted 26 March 2021. 